\title{
ADVANCED PROCEDURE FOR THE MONITORING OF SETTLEMENT AND OPEN SPACE DEVELOPMENT ON BASIS OF TOPOGRAPHICAL GEODATA SETS IN THE IOER-MONITOR
}

\author{
G. Meinel ${ }^{\mathrm{a}}$ \\ ${ }^{a}$ Leibniz Institute of Ecological Urban and Regional Development, Weberplatz 1, 01217 Dresden/Germany, \\ G.Meinel@ioer.de
}

Joint Research Workshop “Geospatial Data Infrastructure: from data acquisition and updating to smarter services”

\begin{abstract}
KEY WORDS: Land Use Monitoring, Basic Topographic Geodata, Settlement Analysis, GIS, Automatic Calculation, Sustainability Indicators, Topographic Raster Maps
\end{abstract}

\begin{abstract}
:
Concept, Procedures and Results of the Monitor of settlement and open space development are presented. The monitoring system will describe the state and the development of land use especially in regard to its sustainability for the entire Federal Republic of Germany. To this end, for the first time ever it makes use of topographical geobasis data (digital landscape model of the Authoritative Topographic-Cartographic Information System, short ATKIS). These data allow for a more precise spatial and contentwise description of land use than that of the land register data, which serve as the basis for the official land use statistics. On the basis of the geobasis data an automatic calculation of indicators from the fields of settlement, open space, nature reserves, population, traffic occurs and landscape fragmentation. The indicators are depicted in thematic maps, thus allowing for spatial and chronological comparisons. In addition to administrative spatial units (federal state, region, district, municipality), the indicator values are also presented in scales of various cell widths. For calculating building-based settlement indicators, the patented program SEMENTA ${ }^{\circledR}$ is used, which is based on an automated evaluation of analogue maps.
\end{abstract}

\section{INTRODUCTION}

One key element of the national sustainability strategy of the German Federal Government is the economical and careful handling of the finite resource of land. The targeted goal is to reduce the amount of land use for settlement and traffic purposes to 30 ha/day by 2020 for Germany (among others, Dosch, 2008). The "traffic light report" from the Council for Sustainable Development (RNE, 2008) shows that, on account of the fact that the current value is $104 \mathrm{ha} /$ day, the traffic light is red and thus the targeted goal lies in the distant future. For this reason, the existing tools of economical land use must be reviewed. In addition to legal and fiscal instruments, the informational instruments in particular must be expanded and improved because the current information regarding land use and its changes only allow for a very limited assessment of the development.

In Germany, the surveying administrations and land registry authorities of the federal states obtain land use data from the real estate book (Automated Land Register ALB), aggregate this information and then pass it on in the form of federal land use statistics to the Federal Statistical Office of Germany. However, earlier changes and the now tarnished readjustments of the ALK database to the official real estate register's information system ALKIS have led to flaws in the time series. Additional points of criticism concerning the official land use statistics result from the fact that certain allocations of land use are specific to certain federal states and that there is outdated and incomplete information used. Thus, the chronological and spatial comparability of the data is limited (Federal Statistical Office of Germany, 2008). The greatest deficiencies concerning the assessment and evaluation, however, arise from the spatial resolution: the plot-based survey of the values through the attribute of main type of use conceals the differentiated, actual land cover. At the same time, the aggregation of the values on larger territorial units prevents there from being locally differentiated information concerning issues such as the previous use of land, settlement structure, the state of new settlement areas and their traffic accessibility.

For some time now, the institutions of the ordnance survey and of the Federal Agency for Cartography and Geodesy (BKG) have been making available basic digital geodata with the help of the Authoritative Topographic-Cartographic Information System (AKTIS $\AA$ ) that describes the nation-wide land use in a topographical manner in a highly spatial resolution. Since most of the errors that plagued earlier versions have been fixed in the third version of the system, it is time to begin making use of these data also for indicator-based, land use statistical reports.

\section{CONCEPT OF THE MONITOR OF SETTLEMENT AND OPEN SPACE DEVELOPMENT (IOER- MONITOR)}

The Leibniz Institute of Ecological Urban and Regional Development (IOER) has the goal of describing land use and its development nation-wide for Germany in a continuous, spatial and a high-resolution manner with the help of suitable indicators so as to add to the official land use statistics. This Monitor of settlement and open space development (IOERMonitor) should also allow for spatial and chronological comparisons on the basis of topographical basic geodata (e.g. regarding the location and density of buildings as well as the issue of the development of building stock) and thus a better evaluation of the sustainability of the development via policies and management (Table 1). 


\begin{tabular}{|c|c|c|}
\hline & $\begin{array}{l}\text { Official Land } \\
\text { Use Statistics }\end{array}$ & $\begin{array}{c}\text { Monitor of the Settlement } \\
\text { and Open Space } \\
\text { Development (IOER- } \\
\text { Monitor) }\end{array}$ \\
\hline Data basis & $\begin{array}{l}\text { Automated real } \\
\text { estate register } \\
\text { (ALB) }\end{array}$ & $\begin{array}{c}\text { Digital landscape model of } \\
\text { ATKIS } \AA \text { and digital } \\
\text { topographic maps } 1: 25,000 \\
\text { DTK25(-V) }\end{array}$ \\
\hline Survey unit & $\begin{array}{l}\text { Plot size and } \\
\text { main type of } \\
\text { use }\end{array}$ & $\begin{array}{l}\text { Topographic objects such } \\
\text { as buildings, building } \\
\text { blocks, streets, open spaces } \\
\text { (AKTIS object types) }\end{array}$ \\
\hline $\begin{array}{l}\text { Smallest } \\
\text { published } \\
\text { spatial unit }\end{array}$ & $\begin{array}{l}\text { County, } \\
\text { district, } \\
\text { municipality }\end{array}$ & $\begin{array}{l}\text { Municipalities, building } \\
\text { blocks and grid cells }\end{array}$ \\
\hline $\begin{array}{l}\text { Description } \\
\text { of land use }\end{array}$ & $\begin{array}{l}\text { Factual data } \\
\text { about counties, } \\
\text { quantitatively } \\
\text { aggregated }\end{array}$ & $\begin{array}{l}\text { Quantitative and } \\
\text { qualitative high-resolution, } \\
\text { evaluation of positional } \\
\text { relationships (density and } \\
\text { proximity in regard to } \\
\text { buildings, terrain and } \\
\text { protected areas) }\end{array}$ \\
\hline $\begin{array}{c}\text { Suitability } \\
\text { for } \\
\text { differentiated } \\
\text { sustainability }\end{array}$ & Less suitable & $\begin{array}{l}\text { Suitable for illustrating } \\
\text { efficiency, utilization } \\
\text { structure, protection, } \\
\text { maintenance and reduction } \\
\text { goals }\end{array}$ \\
\hline $\begin{array}{c}\text { Results and } \\
\text { visualization }\end{array}$ & $\begin{array}{l}\text { Static in tables } \\
\text { and maps }\end{array}$ & $\begin{array}{l}\text { Also online, interactive and } \\
\text { dynamic (SVG and } \\
\text { WebGIS based) }\end{array}$ \\
\hline
\end{tabular}

Table 1. Comparison of the Official land use statistics and the Monitor of settlement and open space development (IOER-Monitor)

\subsection{Indicators and Parameters}

For depicting the settlement and open space development suitable "measurement values" must be found in order to represent the complex sets of facts that are often hard to measure directly. In the monitoring process, indicators as well as parameters are calculated and visualized. While indicators quantify selected complex data, the parameters represent facts and underlying values and contribute to the understanding of the indicators. The categories of "Settlement," "Open Space," "Landscape Protection", "Nature Conservation" and "Population," later expanded around the thematic fields of "Traffic" and "Materials/Energy" structure the Monitor and contain the categorized indicators and parameters (Table 2). When determining the individual indicators, it is essential to reconcile an adequate description of the conditions and processes of the real world with the reliability of the available basic information (data quality) as well as to carry out the methodological and technological implementation (modelling and calculating) in an efficient manner. To this end, in the research project "Sustainability Barometers of Land Use" ("Nachhaltigkeitsbarometer Fläche", Siedentop et al., 2007), among other things, indicators were theoretically developed that now, at least partially, can be calculated in the IOER-Monitor currently under development.
Building, traffic and technical infrastructure do not by any means always develop in a manner that conforms to settlement policy goals regarding quantity (maximum of 30 ha detached area per day) and structure (inner-city development before outer-city development, good traffic accessibility). For regular and small-scale monitoring of these processes, parameters and indicators must be developed on the basis of individual buildings. In addition to the settlement area, the open space area should be described, that is, the percentage of the total area without any settlement and traffic use. Here the focus is on the state and development of the various forms of land use and land conflicts, including, for instance, issues such as the proximity to nature and the intensity of land use as well as the percentage of settlement and traffic areas in landscapes deserving protection and, generally speaking, the issue of landscape fragmentation.

\begin{tabular}{|c|c|}
\hline Indicator & Short Description \\
\hline \multicolumn{2}{|r|}{ Settlement Indicators } \\
\hline $\begin{array}{l}\text { Percentage of } \\
\text { settlement area } \\
\text { differentiated } \\
\text { according to type } \\
\text { of use }\end{array}$ & $\begin{array}{l}\text { Housing and mixed use, industrial and } \\
\text { commercial areas, areas of a special } \\
\text { functional character }\end{array}$ \\
\hline Building density & $\begin{array}{l}\text { Number of buildings per ha of building } \\
\text { block }\end{array}$ \\
\hline $\begin{array}{l}\text { Density of } \\
\text { building surface } \\
\text { area }\end{array}$ & $\begin{array}{l}\text { Percentage of the building's surface area } \\
\text { on building blocks (=percentage of } \\
\text { constructed land) }\end{array}$ \\
\hline Floor area density & $\begin{array}{c}\text { Percentage of floor area density } \\
\text { (constructed area * number of floors) on } \\
\text { the building block }\end{array}$ \\
\hline $\begin{array}{c}\text { Building volume } \\
\text { density }\end{array}$ & $\begin{array}{l}\text { The ratio of the building volume to the } \\
\text { block area in } \mathrm{m}^{3} / \mathrm{m}^{2}\end{array}$ \\
\hline Housing density & $\begin{array}{l}\text { Number of housing units per ha of } \\
\text { building block }\end{array}$ \\
\hline Population density & $\begin{array}{l}\text { Number of inhabitants per ha of building } \\
\text { block }\end{array}$ \\
\hline Use density & $\begin{array}{l}\text { Inhabitants for each ha of building } \\
\text { surface area }\end{array}$ \\
\hline $\begin{array}{l}\text { Settlement areas at } \\
\text { risk due to } \\
\text { flooding }\end{array}$ & $\begin{array}{l}\text { Number of buildings and building } \\
\text { surface area in flooded areas including } \\
\text { their changes }\end{array}$ \\
\hline \multicolumn{2}{|r|}{ Open Space Indicators } \\
\hline $\begin{array}{l}\text { Percentage of } \\
\text { protected areas }\end{array}$ & $\begin{array}{l}\text { Percentage of protected areas, nature } \\
\text { conservation, protection of species and } \\
\text { landscape conservation }\end{array}$ \\
\hline $\begin{array}{c}\text { Proximity to } \\
\text { nature of the open } \\
\text { spaces }\end{array}$ & $\begin{array}{l}\text { Assessment of the open spaces on the } \\
\text { basis of the proximity to nature } \\
\text { (Hemerobie) }\end{array}$ \\
\hline $\begin{array}{l}\text { Construction on } \\
\text { fertile soil }\end{array}$ & $\begin{array}{l}\text { Percentage of fertile soil among } \\
\text { settlement and traffic areas }\end{array}$ \\
\hline Biotope structure & $\begin{array}{c}\text { Density of landscape elements in open } \\
\text { land }\end{array}$ \\
\hline Noise corridors & $\begin{array}{l}\text { Areas in differentiated noise bands and } \\
\text { their percentage of open space }\end{array}$ \\
\hline $\begin{array}{l}\text { Exploitation of } \\
\text { protected areas }\end{array}$ & $\begin{array}{c}\text { Number of buildings and building area in } \\
\text { protected areas (degree of } \\
\text { fragmentation); road network in } \\
\text { protected areas }\end{array}$ \\
\hline
\end{tabular}

Table 2. Selected indicators of the Monitor of settlement and open space development (IOER-Monitor)

All parameters and indicators will be calculated in high resolution. When published on the internet, the values will be 
applied to different territorial units. Depending on whatever makes sense, these will be administrative units, selected natural area units or units relevant for planning purposes. In the settlement area, the building block will be the smallest calculating unit.

In order to create long-standing, stable time series, indicators will not only be calculated on the basis of administrative areas but also for quadratic grid cells of various sizes $(125 \mathrm{~m}, 250 \mathrm{~m}$, $500 \mathrm{~m}, 1000 \mathrm{~m}$ ). This measured breakdown will improve the comparability of the data both chronologically and spatially and thus will support various forms of research not only at a micro, regional and trans-regional level but also at the national level (Wonka, 2008).

\subsection{Base Data}

The topographic base data for a Germany-wide monitoring of land use must be comprehensive in nature and, as far as possible, homogenized. The continued storage of the data must also be secured in a legal manner so as to ensure that also in the future monitoring will be possible on the basis of stable time series. Thus, the Official Topographic-Cartographic Information System (AKTIS) in the form of the Digital Basic Landscape Model (DLM) is especially suited for this purpose on account of its high resolution (surveying scale 1:10,000) and it's officially required updating of the data, which serves as the basis for the descriptions and assessments of land use in Germany.

The detailed assessment of settlement development is based on changes in the building stock and traffic infrastructure. It is also only in this manner that questions concerning the location, networking, density and use of settlement structures can be answered. Thus, for the monitoring building sketches with and without a limited generalization are required. Although this level of detail has a strong effect on the volume of data and calculating time, which becomes squared with higher resolutions, the crucial point, however, is the availability of this geo information.

The homogenized ATKIS Digital Basic Landscape Model, which the Federal Agency for Cartography and Geodesy (BKG) makes available for nation-wide analyses, does not currently have any layer on the building stock. Since indicator values, however, should be determined and the digital terrain data have only recently been available in a comprehensive manner with sufficient levels of high resolution, it is necessary to have access to analogue and digital editions of topographic maps. A presentation of the availability, problems and a quality assessment of the base data can be found in Meinel et al. (2008a).

For the calculation of parameters related to settlement structure, a program called SEMENTAC (Meinel et al., 2008b), which was developed at the Leibniz Institute of Ecological and Regional Development, can be used. It filters, vectorizes, surveys and classifies buildings from the ground plan layer of the topographic map in scale 1: 25.000 (TK25 and DTK25(-V)) by means of digital image processing. On the basis of the building floor plans, which have been integrated in this manner, numerous indicators based on both buildings and building blocks such as construction density, floor area density and building volume density can be calculated. In addition, a module entitled SEMENTA(C-CHANGE has been developed in the meantime, which allows for a building-based analysis of settlement development.
Methods of spatial disaggregation should be used to relate land use data to statistical data so as to obtain small-scale information. To this end, databases such as "GENESIS-online" and "Statistik local" are used as well as other sources of information from the regional and federal government. For deriving additional indicators and parameters (in regard to soil, noise etc.), geodata from various thematic fields must be integrated. Thus, for instance, in the monitoring system the geometries of the protected areas from the Federal Office for Nature Conservation are used.

\subsection{Data Management}

The high-resolution, Germany-wide evaluation requires an enormous volume of data. Thus, the ATKIS Basis-DLM in the digital storage format File-Geodatabase (fGDB) requires 27 gigabytes for one specific point in time alone. Parallel with saving geodata in an fGDB, the calculated indicator values of the various territorial units are stored in a MySQL database. In this manner, by means of a SVG-based map viewer, it is possible to create a quick and simple visualization of the indicators and parameters.

Before being able to calculate the indicators, the ATKIS data require various steps of preparation and quality assurance (Figure 1). Thus, the permitted land use overlaps in the AKTIS model require the creation of corrected sets of geodata, which also depict real states of land use in a statistically correct manner. On the other hand, the calculating of the traffic areas forces the buffering of the traffic roads, which are only digitized as lines. For the attribute of "road width," which is frequently lacking especially when it comes to communal roads, empirically determined default values are used. Recurring preparation that is dependent on time periods and the processing of the geodata require a high degree of automation, which is achieved in the monitoring especially via Python scripting.

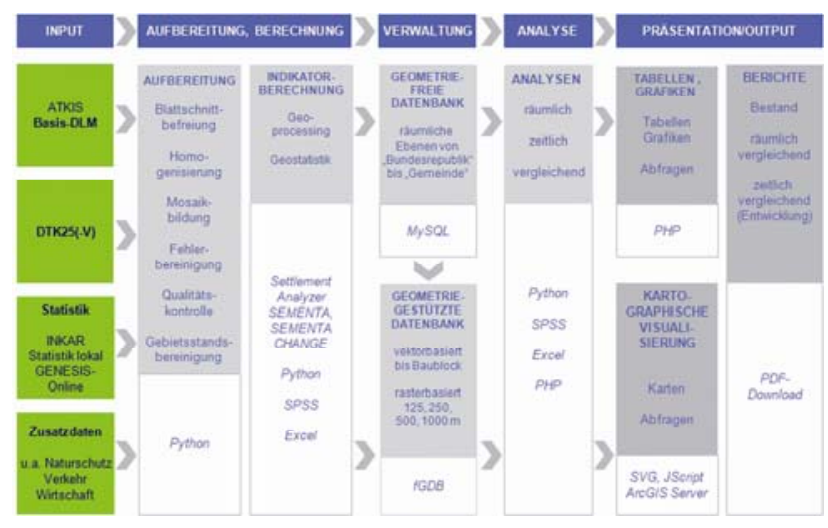

Figure 1. Workflow of the Monitor of settlement and open space development (Project documentation, IOER, 2009)

\section{VISUALIZATION OF THE INDICATORS}

The results of the Monitor of settlement and open space development (IOER-Monitor) published on the internet since 2010. On the main page of the website presented in addition to a map with current results serving as an eye-catcher, goals, databases and implementation stages of the monitoring process. For the geovisualization of the calculated indicators, there are two 
map viewers with their own form of technology and each one is meant for different levels of exploration: a simple, user-friendly viewer that provides users with overviews on the basis of SVG which goes all the way down to the municipal level (smaller to medium-sized scale) and later a detail viewer that operates on the basis of web mapping, which is conceived for more in-depth, spatial analyses (medium-sized to large scale).

For a better understanding of the map contents a document for each indicators will also be provided, which will explain both the concepts and the calculation methodology. Tables, graphics and diagrams will provide concrete values and time series for selected geographical units.

\subsection{A Viewer Based on SVG}

The viewer allows for the very simply visualization of the calculated indicators via a web browser. In comparison with the large and inflexible Adobe Flash files, it is advisable to use the W3C standard scalable vector graphics (SVG) with its open, standardized XML structure, which can be generated in a simple manner with every available programming language. To do this, however, at present it is necessary to install a plug-in on the (proprietary) web browser Internet Explorer (IE). An XHTML document controls the visual presentation in the viewer screen and also reacts to the user preferences for the map in regard to time (year), topic (category and indicator) and area (extension, level of administration level and areas to be displayed) (Figure 2, above-left). The desired map will be displayed in the default manner with colour classifications, which are adapted to the respective range of values ensuring a good level of differentiation of the spatial units.

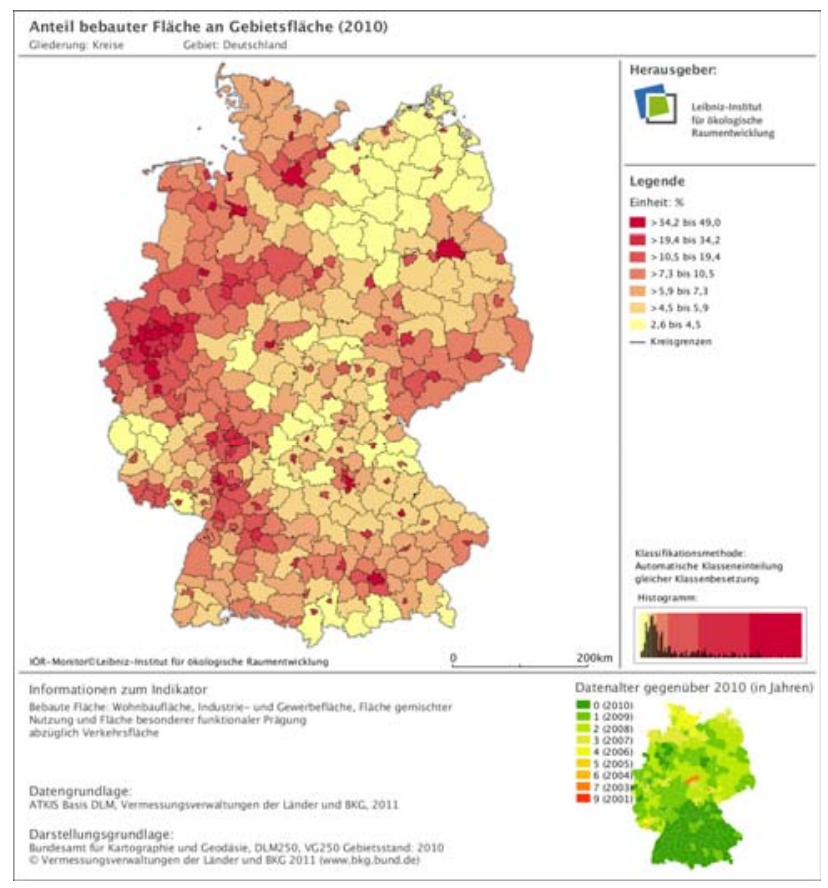

Figure 2. Viewer of the IOER-Monitor

Users, however, can specify the map in regard to both content and graphics via buttons (Figure 2 centre-left) as follows:

- Selecting display methods for the indicator values (continuous color gradient, manual selection of color for each class or automatic selection of the color based on the frequency distribution of the indicator values),
- defining colors for color scales and text,

- fixing the reference to "Germany-wide" or "local specific maps" and

- saving an individualized map (which can also be sent as a link).

The SVG document in the map window (Figure 2, centre) brings together geometry and attributes. The geometry data of the administrative structure VG250 (BKG) were generalized, saved in a PostgreSQL database with the PostGIS extension and, if requested by users, passed in real time to the program as datasets of SVG coordinates. The attribute data are determined in a script-driven manner for every year to be calculated and for every territorial unit and then are stored in a MySQL database. When users request the database to do so, the corresponding attribute and indicator value are linked to the territorial unit via the official municipal key and represented with automatically generated imagery. Furthermore, additional information can be added to the viewer (e.g. geonames or creation dates of the original Geodata).

\subsection{Table Tool}

In a table tool, the selected indicators for the represented territorial units together with their average updated time values are listed in tabular form. The table can be sorted on the basis of the name of the territory or the indicator value. The value of other time periods can optionally also be added, which allows for the comparison of changes. Furthermore, the values of higher administration units can be added to. In such cases, the deviations are also depicted as a numerical value and in a graphical manner, which makes it easier to do spatial comparisons.

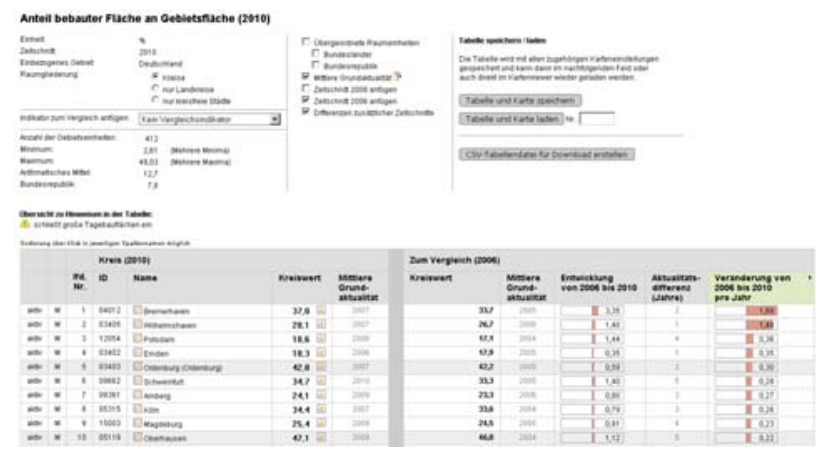

Figure 3. Tables showing the indicator values as well as a comparison

\subsection{Detail Viewer}

The detail viewer serves the purpose of visualizing the indicator values on a larger scale. It allows for the actual situation below the municipal level to be displayed such as districts and building blocks and also makes it possible for previously calculated raster maps to be displayed in various cell sizes. The basis for all this is a web mapping application, which based on the server-side on ArcGIS Server and on the client-side on OpenLayers. For the implementation of the detail viewer, JavaScript and PHP were used as the programming languages and the database MySQL was used for managing the information. The user-friendly display allows for simple and intuitive operation. The display shows the choice of location, time period and indicator. Users also have the option of adding their own data in the form of WMS layers and visualizing orthophotos by Google Maps in the background. The latter helps to 
better understand and evaluate the indicator values.

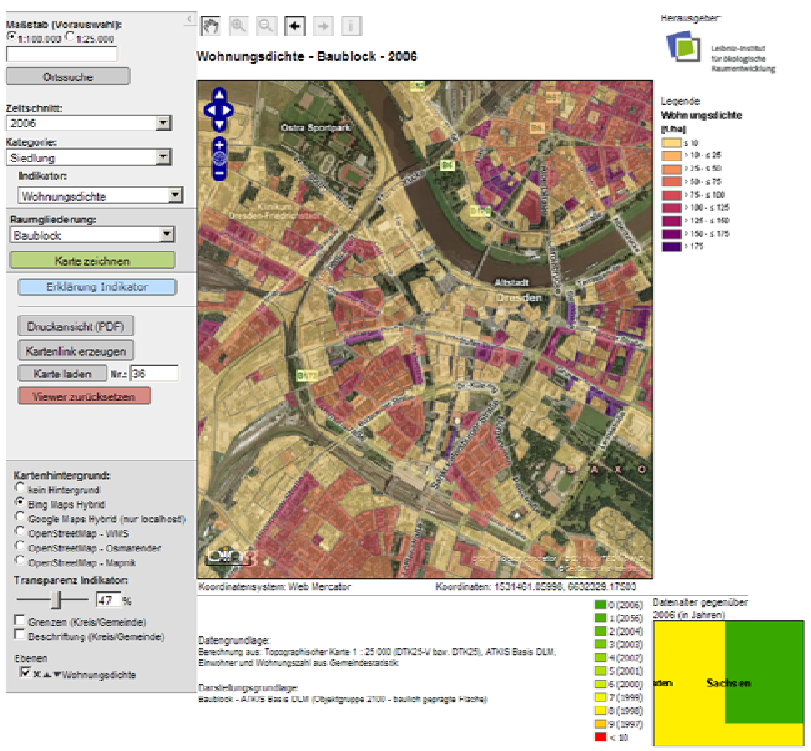

Figure 4. View of the indicator's block-based building surface area in the detail viewer for the city of Dresden

\subsection{Application Example}

The AKTIS object type "industrial and commerce areas" (2112) contains built-up areas, which exclusively or predominately serve to accommodate industrial and commercial enterprises. This also includes, for instance, shopping centers, stock-rooms, warehouses, large scale trading companies, utility companies and waste disposal companies (AKTIS object type catalogue). In the monitoring system, this type of land use is calculated on the basis of various reference units. Related to the settlement area (Figure 5), the presentation essentially contains more relevant information than in the "classical" presentation form, which is based on administrative units (Figure 5 left). The indicator of the category "inhabitants" relates the industrial/commerce area to the inhabitants of the territorial unit (Figure 5 right) and thus provides additional criteria for evaluating the efficiency of the land use.
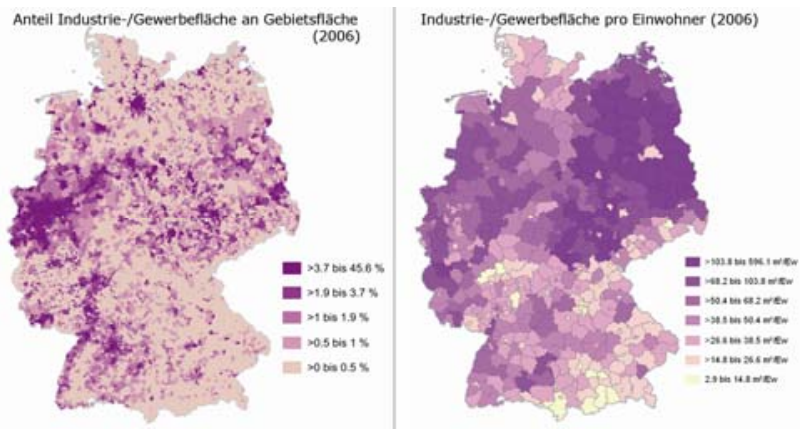

Figure 5. left: percentage of the industrial/commerce area (municipalities), right: industrial/commerce area per inhabitant (counties) for 2006

Varying the method of displaying the data in different classes helps users to effectively explore the information. Experts thus have at their disposal an important tool for interpreting regional and local conditions as well as extreme values in addition to uncovering connections, making qualified evaluations and determining options for action.

\section{OUTLOOK}

The implementation of the monitoring concept is finished and the monitor in German language is online since 2010 (www.ioer-monitor.de). On account of the high spatial resolution, it is expected that there will be wide interest in the project, including also regional and local actors. The calculation of the indicators will occur at regular two year intervals for each federal state. For selected indicators, however, it is planned for this to occur at shorter intervals. Gradually, additional indicators will be added and - thanks to the automatic evaluation of the TK25 - also earlier time slots will be added to the monitoring system. Furthermore, the indicators will be calculated and visualized on grid cells (geogrids). Thus, the foundations will be laid for a wider range of regional statistics. In the future, relevant statistical parameters regarding population, housing, construction, economics and traffic increasingly should also be regionalized on the basis of the high resolution land use data. To this end, methods of spatial disaggregation, among other things, must be further developed.

\section{REFERENCES}

AAA-Dokumentation zur Modellierung der Geoinformationen des amtlichen Vermessungswesens (GeoInfoDok), ATKISKatalogwerke, ATKIS-Objektartenkatalog Basis-DLM, Version 6.0, Stand: 11.04.2008

Amtliches Topographisch-Kartographisches Informationssystem (ATKIS): aktueller Objektartenkatalog Basis-DLM, 2003; Dokumentation zu Vektordaten Digitales Basis-Landschaftsmodell 2005; Bundesamt für Kartographie und Geodäsie, www.atkis.de/dstinfo/

Dosch, F. (2008): Siedlungsflächenentwicklung und Nutzungskonkurrenzen, Schwerpunkt: Flächennutzungskonflikte - Ursachen, Folgen und Lösungsansätze, In: Technikfolgenabschätzung - Theorie und Praxis, Hrsg: Institut für Technikfolgenabschätzung und Systemanalyse (ITAS), Nr. 2, 17. Jahrgang - September 2008, S. 41-51

INSPIRE (2007): Richtlinie 2007/2/EG des Europäischen Parlaments und des Rates vom 14. März 2007 zur Schaffung einer Geodateninfrastruktur in der Europäischen Gemeinschaft (INSPIRE). Amtsblatt der Europäische Union http://eurlex.europa.eu/JOHtml.do?uri=OJ\%3AL\%3A2007\%3A108\%3A SOM\%3ADE\%3AHTML

Meinel, G.; Knop, M.; Hecht, R. (2008a): Qualitätsaspekte und Verfügbarkeit digitaler Geobasisdaten in Deutschland unter besonderer Berücksichtigung des ATKIS ${ }^{\circledR}$ Basis-DLM und der DTK25(-V). PFG 1/2008, S. 29-40

Meinel, G., Hecht. R.; Herold, H., Schiller, G. (2008b): Automatische Ableitung von stadtstrukturellen Grundlagendaten und Integration in einem Geographischen Informationssystem, Forschungen Heft 134, Herausgeber BBR, Bonn

Meinel, G.; Hecht, R.; Herold, H. (2009): Verfahren zur Erhebung, Analyse und Visualisierung von Gebäudebestandsund Siedlungsentwicklungen auf Grundlage Topographischer Kartenreihen. Land Use Economics and Planning - Discussion Paper Series, No. 09-07, University of Goettingen 
RNE - Rat für nachhaltige Entwicklung (2008): Welche Ampeln stehen auf Rot? Stand der 21 Indikatoren der nationalen Nachhaltigkeitsstrategie - auf der Grundlage des Indikatorenberichts 2006 des Statistischen Bundesamtes. Stellungnahme des Rates für Nachhaltige Entwicklung, Berlin http://www.nachhaltigkeitsrat.de/uploads/media/Broschuere_Ampel_texte_N r_22_April_2008_01.pdf

Siedentop, S. et al (2007): Regionale Schlüsselindikatoren nachhaltiger Flächennutzung für die Fortschrittsberichte der Nationalen Nachhaltigkeitsstrategie - Flächenziele (,Nachhaltigkeitsbarometer Fläche'), Bonn: Bundesamt für Bauwesen und
Raumordnung 2007. $=$ Forschungen, Band 130

Statistisches Bundesamt (2008): Flächenerhebung nach Art der tatsächlichen Nutzung - Jährliche Erhebung der Siedlungs- und Verkehrsfläche.Qualitätsbericht. www.destatis.de/jetspeed/portal $/ \mathrm{cms} /$ Sites/destatis/Internet/DE/Content/.../Qualitaetsbericht e/.../Siedlverkehrsflaeche,property=file.pdf

Wonka, E. (2008): Regionalstatistik in Österreich auf der räumlichen Bezugsbasis von regionalstatistischen Rastereinheiten. Statistik Austria, Salzburg Wien, 2008 